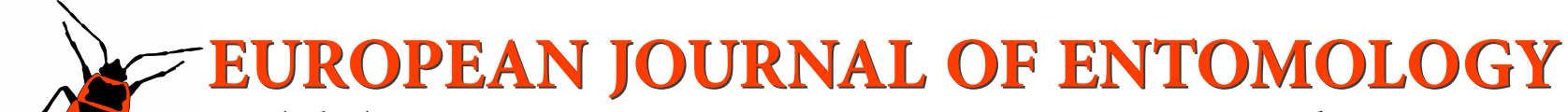 \\ ISSN (online): 1802-8829 \\ http://www.eje.cz \\ Eur. J. Entomol. 115: 658-667, 2018 \\ doi: 10.14411/eje.2018.065 \\ ORIGINAL ARTICLE
}

\section{Overwintering of ladybirds (Coleoptera: Coccinellidae) on Scots pine in Central Europe}

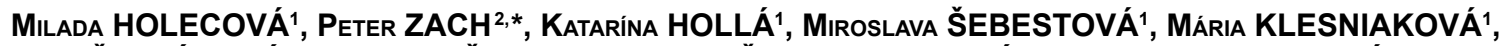 \\ ANNA ŠESTÁKOVÁ ${ }^{3}$, AloIs HONĚK ${ }^{4}$, OLdŘICH NEDVĚD ${ }^{5,6}$, MICHAL PARÁK $^{2}$, ZdeNKA MARTINKOVÁ4 ${ }^{4}$, JuRAJ HOLEC ${ }^{7,8}$, \\ SANDRA VIGLÁŠOVÁ ${ }^{2}$, Peter M.J. BROWN ${ }^{9}$, Helen E. ROY ${ }^{10}$ and Ján KULFAN ${ }^{2}$ \\ ${ }^{1}$ Comenius University, Faculty of Natural Sciences, Department of Zoology, Bratislava, Slovak Republic; \\ e-mails: milada.holecova@uniba.sk, holla24@uniba.sk, miroslava.kupkova@gmail.com, klesniakova1@uniba.sk \\ ${ }^{2}$ Institute of Forest Ecology, Slovak Academy of Sciences, L'. Štúra 2, 96053 Zvolen, Slovak Republic; e-mails: zach@ife.sk, \\ kulfan@ife.sk \\ ${ }^{3}$ The Western Slovakia Museum, Trnava, Slovak Republic; e-mail: sestakova.anna@zupa-tt.sk \\ ${ }^{4}$ Crop Research Institute, Drnovská 507, 16106 Prague 6, Czech Republic; e-mails: honek@vurv.cz, martinkova@vurv.cz \\ ${ }^{5}$ University of South Bohemia, Faculty of Science, 37005 České Budějovice, Czech Republic; e-mail: nedved@prf.jcu.cz \\ ${ }^{6}$ Biology Centre of the Czech Academy of Sciences, Institute of Entomology, 37005 České Budějovice, Czech Republic \\ ${ }^{7}$ Slovak Hydrometeorological Institute, Bratislava, Slovak Republic; e-mail: holec@shmu.sk \\ ${ }^{8}$ Comenius University, Faculty of Natural Sciences, Department of Physical Geography and Geoecology, Bratislava, Slovak \\ Republic; e-mail: juraj.holec@uniba.sk \\ ${ }^{9}$ Applied Ecology Research Group, Department of Biology, Anglia Ruskin University, Cambridge, United Kingdom; \\ e-mail: peter.brown@anglia.ac.uk \\ ${ }^{10}$ NERC Centre for Ecology \& Hydrology, Crowmarsh Gifford, Oxfordshire, United Kingdom; e-mail: hele@ceh.ac.uk
}

Key words. Coleoptera, Coccinellidae, ladybirds, Pinus sylvestris, diapause, overwintering, temporal changes, Central Europe

Abstract. We surveyed ladybirds (Coleoptera: Coccinellidae) in 10 stands of Scots pine (Pinus sylvestris), all monoculture stands 5-100 years old, in western Slovakia, Central Europe, over two successive periods, October 2013-March 2014 and October 2014 - March 2015. The winter in each period was exceptionally mild. Ladybirds were collected from the lower branches of pine trees using beating trays and were present in $61 \%$ of the 1040 samples (one sample containing ladybirds from 20 branches, $1 \mathrm{~m}$ long each). In total 3965 individuals of 20 species were recorded. Non-conifer dwelling species associated with broadleaved trees or herbaceous plants prevailed (45\% of species), followed by conifer specialists (40\%) and generalists (15\%). Although 13 species were found at least in one winter month, December, January or February, only four of them, Exochomus quadripustulatus, Coccinella septempunctata, Harmonia axyridis and Hippodamia variegata, were recorded continually during both winters. The number of species, the abundance of all ladybirds and the abundance of dominant species (E. quadripustulatus, C. septempunctata and $H$. axyridis) decreased from late autumn towards winter and remained lowest during this most adverse time of the year for ladybirds. Overwintering species assemblages of ladybirds changed over time and varied with age of pine stand. Our results suggest that Scots pine in Central Europe supports species rich assemblages of ladybirds from late autumn to early spring and, being widely distributed, it could be suited to winter surveying of ladybirds at large spatial scales to reveal behavioural and ecological responses of species to changing weather or different climates.

\section{INTRODUCTION}

Overwintering is an important phase of an insect's life in temperate areas. For ladybirds (Coleoptera: Coccinellidae) it is passed in the adult stage. As for other periods of the life-cycle of ladybirds, the ecology of overwintering has received much attention (Majerus, 1994; Hodek \& Honěk, 1996; Hodek, 2012a, b; Hodek et al., 2012). To overcome unfavourable cold weather and scarcity of food during winter, ladybirds enter a period of dormancy and select suitable overwintering habitats (Majerus, 1994). There is considerable variation in the type of dormancy sites chosen by particular ladybird species (Majerus, 2016). Ladybirds spend winter in rock crevices, heaps of stones, leaf litter, tree bases, cones, grass tussocks, standing dry herbs,

\footnotetext{
* Corresponding author; e-mail: zach@ife.sk
} 
dense shrubs, bark crevices, peeled bark as well as buildings and other artificial constructions (Hodek, 1960, 1973; Majerus, 1994; Hodek et al., 2012). Certain species may utilize different types of overwintering sites but often prefer one or a few. Earlier studies mostly focused on overwintering sites of frequent and abundant species such as Coccinella septempunctata Linnaeus (Hemptinne, 1988; Honěk, 1989; Ceryngier, 2000; Honěk et al., 2007), Adalia bipunctata (Linnaeus) (Hemptinne, 1985), Ceratomegilla undecimnotata (Schneider) (Hodek et al., 2012), Myrrha octodecimguttata (Linnaeus) (Puliainen, 1966) and Tytthaspis sedecimpunctata (Linnaeus) (Nedvěd, 2006). The preferred overwintering sites of ladybirds within Europe are provided in Hodek (1973), Majerus (1994), Roy et al. (2011), Hodek et al. (2012) and Nedvěd (2015).

The fast spreading non-native harlequin ladybird Harmonia axyridis (Pallas), influencing biodiversity over large areas (Koch, 2003; Roy et al., 2012), dominates many ladybird communities within Europe (Brown et al., 2008, 2011; Viglášová et al., 2017) where it has been intensively studied from various aspects (Raak-van den Berg et al., 2012; Roy \& Brown, 2015; Honěk et al., 2016; Roy et al., 2016; Sloggett, 2017). This eurytopic invader has been reported from many habitats but with most information from the active periods of its life-cycle, specifically spring, summer and autumn (Adriaens et al., 2008; Roy \& Brown, 2015; Brown \& Roy, 2018). As most of the winter records of $H$. axyridis come from urban areas and/or anthropogenic habitats (Panigaj et al., 2014; Viglášová et al., 2017) there is a need to understand the overwintering ecology of this species in rural habitats.

Herein, we surveyed ladybirds on Scots pine (Pinus sylvestris Linnaeus, Pinaceae), a conifer having a very wide distribution extending the breadth of Eurasia (Rehfeldt et al., 2002). Emphasis was placed on the lower branches of pine trees as an overwintering habitat of ladybirds in the fifth and sixth year after the establishment of $H$. axyridis in Slovakia, Central Europe (Brown et al., 2011; Panigaj et al., 2014). Earlier studies from Western, Central and NorthEastern Europe revealed that Scots pine hosts ladybird species specialised on conifers as well as non-specialist species (Höregott, 1960; Bielawski, 1961; Klausnitzer, 1965, 1967; Hodek, 1973; Bastian, 1982, 1984; Majerus, 1994; Czechowska, 1995a, b; Roy et al., 2011; Nedvěd, 2015). Despite a reasonable understanding of the associations of ladybirds and Scots pine within Europe during spring and summer, there is little information from systematic winter surveys. Indeed not much is known about overwintering of native ladybird species or $H$. axyridis in coniferous forests (Pendleton \& Pendleton, 1997-2016; Hodek, 2012a).

We assessed variation in species richness and abundance of ladybirds in a Scots pine forest in Central Europe from late autumn to early spring. Focusing on ladybirds on the lower branches of pine trees we predicted: (1) species specific assemblages during winter, (2) decrease in abundance of ladybirds from late autumn to winter, and (3) temporal and/or spatial variation in the composition of overwintering species assemblages of ladybirds.
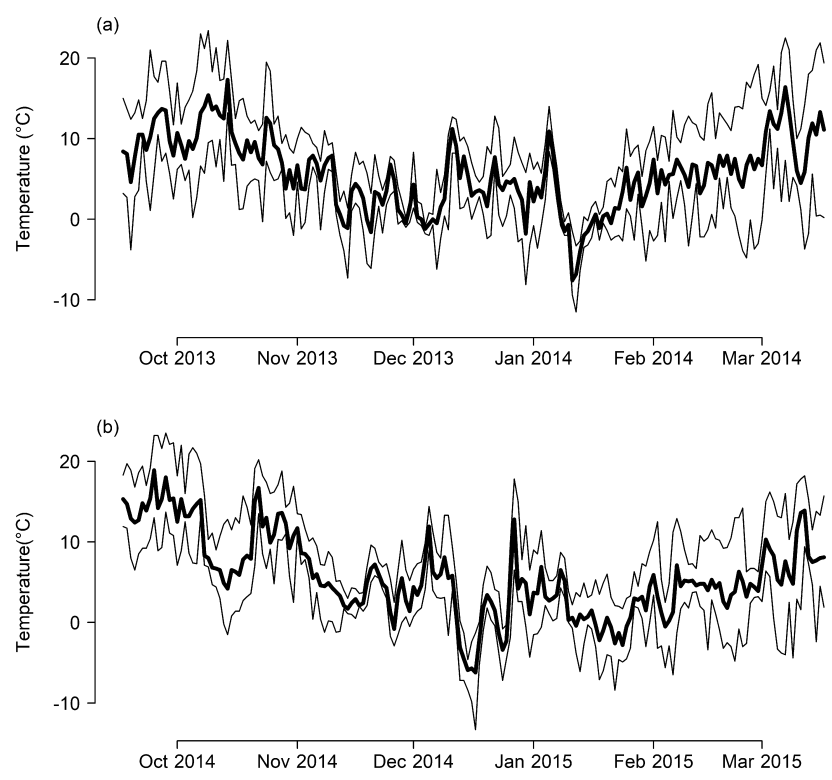

Fig. 1. Air temperatures $\left({ }^{\circ} \mathrm{C}\right)$ in the study area. Average temperatures - thick line, minimum temperatures - thin line below, maximum temperatures - thin line above the average temperatures. Tick marks on the $x$-axis in the middle of each month indicate the approximate collecting times of ladybirds. October 2013-March 2014 (a) and October 2014 - March 2015 (b). Data source: Slovak Hydrometeorological Institute (2016).

\section{MATERIAL AND METHODS}

\section{Study area}

Our study was conducted in the western part of Borská nížina lowland in western Slovakia in the localities of Lakšárska Nová Ves, Studienka, Lozorno, Pernek and Moravský Svätý Ján $(48.333-48.566 \mathrm{~N}, 16.983-17.166 \mathrm{E})$. The area (approximately 30 $\times 20 \mathrm{~km}$ ) is covered by approximately 44,000 ha of monoculture of Scots pine on sand dunes (Šomšák \& Kubíček, 1994) that replaced the former oak-pine forests (Pino-Quercetum; Kollár et al., 2011). It is characterized by a sub-continental climate, with mean annual temperatures varying from 9.0 to $9.6^{\circ} \mathrm{C}$ and mean temperatures in January between -1.0 and $-2.0^{\circ} \mathrm{C}$ (Št'astný et al., 2015). The two successive winters (December-February) of the study were both exceptionally mild, with mean temperature in January of $+2.1^{\circ} \mathrm{C}$ in 2014 and $+2.4^{\circ} \mathrm{C}$ in 2015 . There were 53 subzero days in the winter of 2013/2014 and 46 subzero days in the winter of 2014/2015. Each winter had only a single day with more severe air temperatures of between -10 and $-15^{\circ} \mathrm{C}$ (Fig. 1). In both winters snow cover was reduced to a few days only.

\section{Sampling of ladybirds}

Ladybirds were collected in margins of pine stands (all monoculture stands 5 to 100 years old) with a south-eastern aspect at altitudes between 159 and $222 \mathrm{~m}$ (negligible altitudinal range relative to the size of the area, absence of prominent features of landscape such as hills). The stands bordered forest as well as non-forest habitats - a mosaic of meadows and arable fields. To get insights into changes in abundance and composition of species assemblages over time, ladybirds were repeatedly collected in these stands between October 2013 and March 2014 (the first period) and between October 2014 and March 2015 (the second period), in the middle of each month except for November 2013 when, due to logistical difficulties, ladybirds were not obtained. Seven stands in October and 10 stands in other months were sampled in each period on days without rain, snow or strong wind, between 10:00 and 14:00 $\mathrm{h}$ using beating-trays. One sample con- 
stituted ladybirds from 20 lower branches (up to $3 \mathrm{~m}$ above the ground) of several close-growing trees beaten over a circular canvas beating tray of $1.0 \mathrm{~m}$ in diameter. Young pines (approximately 5 years old) were sampled as whole trees. In each stand samples were always obtained from different marked trees to avoid sampling of branches beaten on previous sampling dates. Visual observations (not quantified) were made to determine the distribution of predominant ladybird species on branches. Ladybirds collected were placed in $70 \%$ ethanol and identified and counted later in the laboratory. Species were classified according to their trophic and habitat preferences following Bielawski (1961), Majerus (1994) and Nedvěd (2015).

\section{Data processing}

(1) The relative occurrence of ladybirds in pine forest was assessed for each species, month and time period as the ratio of the number of samples containing ladybirds and the total number of samples (October: $n=70$, other months: $n=100$ ). The ratio enabled an assessment of the probability of ladybird species recording and the effort needed to obtain particular species over time.

(2) The number of species (species richness), the number of individuals of all species and the number of the three predominant species, Exochomus quadripustulatus (Linnaeus), C. septempunctata and $H$. axyridis (response variables), were modelled as a function of month (categorical explanatory variable with particular months as factor levels). A generalized linear mixed effects model (GLMM, Bolker et al., 2009) with the Poisson distribution and the log link function, was fitted on species richness data (the number of different species on 200 branches). As the variances of ladybird numbers far exceeded the mean values (overdispersion), a GLMM with the negative-binomial distribution and the log link function was fitted on abundance data (the number of individuals on 200 branches). The samples collected monthly in each stand were merged to avoid spatial pseudoreplication, and the temporal dependence in data was considered in the mixed model. In the GLMMs, the factor month was specified as a fixed effect, the factor stand (the 10 repeatedly sampled stands) was considered as a random effect. The post-hoc multiple comparisons of the mean number of species and individuals at the 0.05 significance level were performed using the Tukey's contrasts test, the $P$-values being adjusted by the Holm's method. Mean values along with $95 \%$ confidence intervals were plotted. Diversity of species assemblages in Scots pine forest was characterized by the Simpson's index of diversity calculated for each collecting time. Separate analyses were made for each time period.

(3) To assess the general variability in species data, unconstrained detrended correspondence analysis (DCA) was employed. The species data (abundances) were $\log (\mathrm{x}+1)$ transformed prior to the analysis. The longest DCA axis was the second one with the length of 3.59 units. The rare species were down-weighted as some of them had a strong effect on the ordination. Species data were then fitted in the constrained correspondence analysis (CCA). Species assemblages in October and March (in both periods) differed from the species assemblages in December, January and February $(10,000$ permutations of model residuals; $P<0.01)$. Hence, only the samples from the three winter months were analysed to account for variation in species data. In the CCA overwintering species assemblages were modelled as a function of the month (categorical variable: three winter months), age of forest stand (numerical variable: ages of ten different stands) and type of habitat adjacent to an overwintering habitat (categorical variable: forest/no forest as factor levels).

Statistical analyses were performed in R (R Development Core Team, 2016). The Simpson's index of diversity was calculated using PAST (Hammer et al., 2001).

\section{RESULTS}

Approximately $60 \%$ of the samples from the first $(\mathrm{n}=$ $470)$ and $62 \%$ from the second period $(n=570)$ contained at least one ladybird, hence, ladybirds were present in $61 \%$ of the 1040 samples obtained in both periods. Three species, E. quadripustulatus (Linnaeus), C. septempunctata and $H$. axyridis, occurred most frequently in samples. They were observed to spend winter directly on the exposed bark

Table 1. Relative occurrence (\%) and trophic groups of ladybird species on Scots pine in Central Europe. Continually recorded species during both winters are marked with an asterisk $\left(^{*}\right)$. APH - aphidophage, COC - coccidophage, PAL - pallinophage, PSO - psocopterophage, PSY - psyllophage, PHYL - phyllophage. October 2013-March 2014, October 2014-March 2015. Data from November 2013 are not available.

\begin{tabular}{|c|c|c|c|c|c|c|c|c|c|c|c|c|}
\hline \multirow{2}{*}{$\begin{array}{l}\text { Period } \\
\text { Species / Month }\end{array}$} & \multicolumn{5}{|c|}{$2013 / 2014$} & \multicolumn{6}{|c|}{2014 / 2015} & \multirow{2}{*}{$\begin{array}{l}\text { Trophic } \\
\text { group }\end{array}$} \\
\hline & Oct & Dec & Jan & Feb & Mar & Oct & Nov & Dec & Jan & Feb & Mar & \\
\hline Exochomus quadripustulatus (Linnaeus, 1758)* & 41.4 & 30.0 & 20.0 & 35.0 & 25.0 & 50.0 & 62.0 & 39.0 & 29.0 & 31.0 & 28.0 & $\mathrm{APH}, \mathrm{COC}$ \\
\hline Chilocorus bipustulatus (Linnaeus, 1758) & 42.9 & 5.0 & 0.0 & 6.0 & 53.0 & 0.0 & 1.0 & 2.0 & 2.0 & 0.0 & 6.0 & $\mathrm{COC}$ \\
\hline Chilocorus renipustulatus (L.G. Scriba, 1791) & 0.0 & 1.0 & 0.0 & 0.0 & 2.0 & 0.0 & 0.0 & 0.0 & 0.0 & 0.0 & 0.0 & $\mathrm{COC}$ \\
\hline Rhyzobius chrysomeloides (Herbst, 1792) & 2.9 & 4.0 & 3.0 & 11.0 & 13.0 & 11.4 & 1.0 & 0.0 & 0.0 & 0.0 & 4.0 & $\mathrm{APH}, \mathrm{PAL}$ \\
\hline Anatis ocellata (Linnaeus, 1758) & 1.4 & 0.0 & 0.0 & 0.0 & 0.0 & 1.4 & 1.0 & 0.0 & 0.0 & 0.0 & 0.0 & APH \\
\hline Calvia decemguttata (Linnaeus, 1767) & 1.4 & 0.0 & 0.0 & 0.0 & 3.0 & 0.0 & 0.0 & 0.0 & 0.0 & 0.0 & 0.0 & $\mathrm{APH}, \mathrm{PSO}$ \\
\hline Coccinella magnifica (Redtenbacher, 1843) & 45.7 & 0.0 & 0.0 & 0.0 & 0.0 & 5.7 & 0.0 & 0.0 & 0.0 & 0.0 & 0.0 & \\
\hline Coccinella quinquepunctata Linnaeus, 1758 & 0.0 & 0.0 & 1.0 & 0.0 & 3.0 & 1.4 & 2.0 & 0.0 & 0.0 & 0.0 & 0.0 & APH, PSY \\
\hline Coccinella septempunctata Linnaeus, $1758^{*}$ & 54.3 & 44.0 & 25.0 & 13.0 & 21.0 & 61.4 & 57.0 & 43.0 & 15.0 & 6.0 & 25.0 & $\mathrm{APH}$ \\
\hline Coccinula quatuordecimpustulata (Linnaeus, 1758) & 11.4 & 1.0 & 3.0 & 0.0 & 0.0 & 15.7 & 23.0 & 16.0 & 0.0 & 0.0 & 0.0 & $\mathrm{APH}, \mathrm{PAL}$ \\
\hline Harmonia axyridis (Pallas, 1773$)^{\star}$ & 15.7 & 4.0 & 5.0 & 2.0 & 1.0 & 25.7 & 47.0 & 35.0 & 12.0 & 5.0 & 12.0 & $\mathrm{APH}$ \\
\hline Harmonia quadripunctata (Pontoppidan, 1763) & 4.3 & 1.0 & 0.0 & 0.0 & 8.0 & 25.7 & 2.0 & 0.0 & 0.0 & 0.0 & 16.0 & $\mathrm{APH}$ \\
\hline Hippodamia tredecimpunctata (Linnaeus, 1758) & 0.0 & 0.0 & 0.0 & 0.0 & 1.0 & 0.0 & 3.0 & 2.0 & 1.0 & 0.0 & 0.0 & PH \\
\hline Hippodamia variegata (Goeze, 1777)* & 0.0 & 5.0 & 3.0 & 1.0 & 2.0 & 30.0 & 34.0 & 21.0 & 7.0 & 1.0 & 6.0 & $\mathrm{APH}$ \\
\hline Myrrha octodecimguttata (Linnaeus, 1758) & 0.0 & 0.0 & 0.0 & 0.0 & 0.0 & 4.3 & 2.0 & 0.0 & 0.0 & 0.0 & 3.0 & $\mathrm{APH}$ \\
\hline Myzia oblongoguttata (Linnaeus, 1758) & 0.0 & 0.0 & 0.0 & 0.0 & 1.0 & 0.0 & 0.0 & 0.0 & 0.0 & 0.0 & 1.0 & $\mathrm{APH}$ \\
\hline Oenopia conglobata (Linnaeus, 1758) & 0.0 & 0.0 & 0.0 & 0.0 & 0.0 & 0.0 & 0.0 & 0.0 & 1.0 & 0.0 & 0.0 & $\mathrm{APH}$ \\
\hline Propylea quatuordecimpunctata (Linnaeus, 1758) & 0.0 & 0.0 & 0.0 & 0.0 & 0.0 & 0.0 & 0.0 & 0.0 & 0.0 & 0.0 & 1.0 & $\mathrm{APH}$ \\
\hline Subcoccinella vigintiquatuorpunctata (Linnaeus, 1758) & 7.1 & 0.0 & 0.0 & 0.0 & 0.0 & 10.0 & 8.0 & 2.0 & 0.0 & 0.0 & 2.0 & PHYL \\
\hline Scymnus suturalis Thunberg, 1795 & 0.0 & 0.0 & 0.0 & 0.0 & 13.0 & 0.0 & 0.0 & 0.0 & 0.0 & 0.0 & 21.0 & $\mathrm{APH}$ \\
\hline Number of samples (one sample $=20$ branches) & 70 & 100 & 100 & 100 & 100 & 70 & 100 & 100 & 100 & 100 & 100 & \\
\hline
\end{tabular}




\section{$2013 / 2014$}

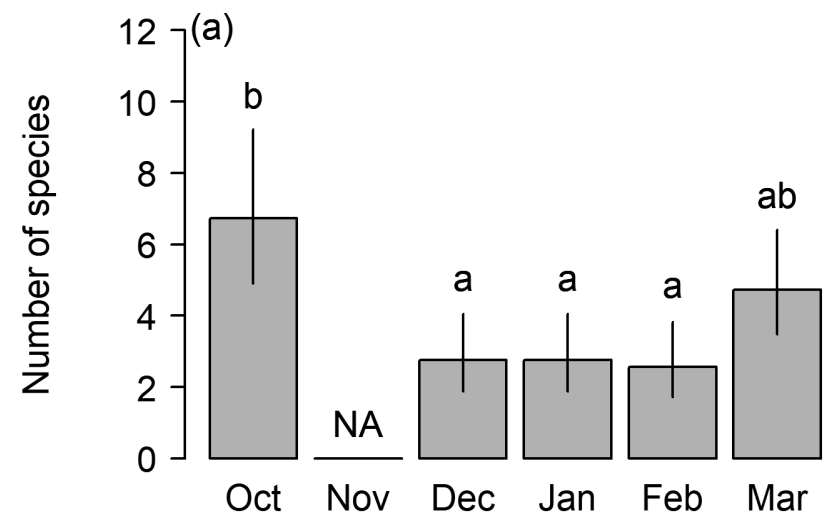

$2014 / 2015$

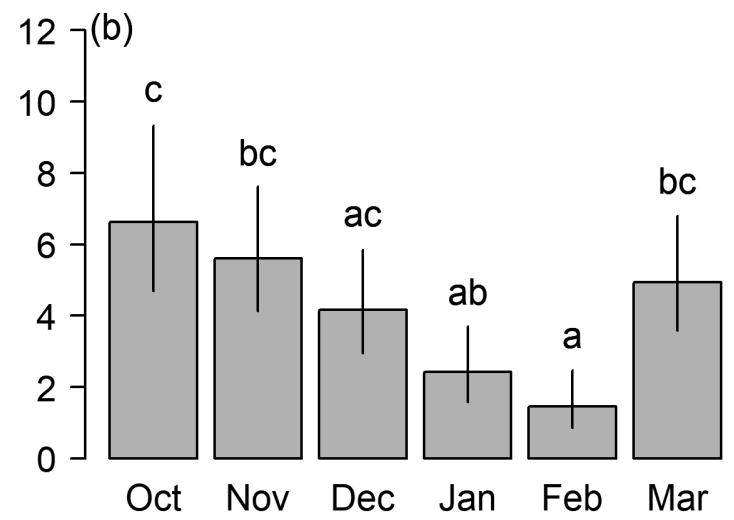

Fig. 2. Number of ladybird species (S) on 200 branches (1 m long each) of Scots pine trees. Columns denote the mean, error bars the $95 \%$ non-parametric bootstrap confidence intervals. Different letters above the error bars indicate significant difference between the means $(P$ $<0.05, P$-values adjusted, controlling the false discovery rate). October 2013-March 2014 (a), October 2014 -March 2015 (b). NA - not available.

of branches (E. quadripustulatus), in the terminal parts of branches (C. septempunctata) or amongst pine foliage in different parts of branches $(H$. axyridis). The relative occurrence of most of the dominant species indicated lower probability of detection during winter than during late autumn. Judged from trophic preferences in the literature, a total of 16 species $(80 \%)$ mainly feed on aphids, three species $(15 \%)$ prefer coccids and one species $(5 \%)$ is a herbivore (Table 1).

In total, 3965 individuals of 20 species belonging to the tribes Chilocorini, Coccidulini, Coccinellini, Epilachnini and Scymnini were recorded. A total of 1440 individuals and 17 species were obtained in the first period, while 2525 individuals and 18 species were recorded in the second pe- riod. Exochomus quadripustulatus and C. septempunctata dominated species assemblages in both periods, and $H$. axyridis and Hippodamia variegata (Goeze) were characteristic predominant species in only the second period (Table 2 ).

The number of species (species richness) changed over the first $\left(\chi_{(4)}^{2}=56.9, P<0.0001\right)$ and the second period $\left(\chi_{(5)}^{2}=80.4, P<0.0001\right.$ ), being consistently (in both periods) lowest during winter (between December and February, Fig. 2a, b). In total 10 species were recorded in the first winter, followed by 9 species in the second winter. Both winters together yielded 13 species $(65 \%$ of the twenty species recorded overall). Of them, E. quadripustulatus, C. septempunctata, H. axyridis and H. variegata occurred

Table 2. Relative abundance of ladybirds (\%), number of individuals (N), number of species (S) and diversity of species assemblages (Simpson's index of diversity) on Scots pine in Central Europe. October 2013-March 2014, October 2014-March 2015. Data from November 2013 are not available.

\begin{tabular}{|c|c|c|c|c|c|c|c|c|c|c|c|}
\hline \multirow{2}{*}{$\begin{array}{l}\text { Year } \\
\text { Species / Month }\end{array}$} & \multicolumn{5}{|c|}{$2013 / 2014$} & \multicolumn{6}{|c|}{$2014 / 2015$} \\
\hline & Oct & Dec & Jan & Feb & Mar & Oct & Nov & $\mathrm{Dec}$ & Jan & Feb & Mar \\
\hline Exochomus quadripustulatus (Linnaeus, 1758) & 43.0 & 33.3 & 45.0 & 85.9 & 36.9 & 42.1 & 29.9 & 29.7 & 45.4 & 91.1 & 30.6 \\
\hline Chilocorus bipustulatus (Linnaeus, 1758) & 11.5 & 2.9 & 0.0 & 3.0 & 36.2 & 0.0 & 0.1 & 0.5 & 1.4 & 0.0 & 4.4 \\
\hline Chilocorus renipustulatus (L.G. Scriba, 1791) & 0.0 & 0.6 & 0.0 & 0.0 & 0.7 & 0.0 & 0.0 & 0.0 & 0.0 & 0.0 & 0.0 \\
\hline Rhyzobius chrysomeloides (Herbst, 1792) & 0.7 & 2.3 & 3.7 & 4.8 & 6.1 & 1.5 & 0.1 & 0.0 & 0.0 & 0.0 & 2.2 \\
\hline Anatis ocellata (Linnaeus, 1758) & 0.2 & 0.0 & 0.0 & 0.0 & 0.0 & 0.1 & 0.1 & 0.0 & 0.0 & 0.0 & 0.0 \\
\hline Calvia decemguttata (Linnaeus, 1767) & 0.2 & 0.0 & 0.0 & 0.0 & 0.7 & 0.0 & 0.0 & 0.0 & 0.0 & 0.0 & 0.0 \\
\hline Coccinella magnifica (Redtenbacher, 1843) & 14.8 & 0.0 & 0.0 & 0.0 & 0.0 & 0.7 & 0.0 & 0.0 & 0.0 & 0.0 & 0.0 \\
\hline Coccinella quinquepunctata Linnaeus, 1758 & 0.0 & 0.0 & 0.9 & 0.0 & 0.9 & 0.3 & 0.2 & 0.0 & 0.0 & 0.0 & 0.0 \\
\hline Coccinella septempunctata Linnaeus, 1758 & 23.2 & 52.3 & 36.7 & 5.2 & 8.5 & 32.0 & 20.3 & 31.3 & 11.3 & 4.4 & 16.4 \\
\hline Coccinula quatuordecimpustulata (Linnaeus, 1758) & 2.2 & 1.1 & 3.7 & 0.0 & 0.0 & 1.6 & 4.6 & 5.0 & 0.0 & 0.0 & 0.0 \\
\hline Harmonia axyridis (Pallas, 1773) & 2.6 & 3.4 & 6.4 & 0.7 & 0.2 & 5.6 & 32.6 & 20.1 & 28.4 & 3.9 & 9.3 \\
\hline Harmonia quadripunctata (Pontoppidan, 1763) & 0.7 & 0.6 & 0.0 & 0.0 & 2.8 & 4.2 & 0.2 & 0.0 & 0.0 & 0.0 & 10.9 \\
\hline Hippodamia tredecimpunctata (Linnaeus, 1758) & 0.0 & 0.0 & 0.0 & 0.0 & 0.2 & 0.0 & 0.4 & 0.5 & 0.7 & 0.0 & 0.0 \\
\hline Hippodamia variegata (Goeze, 1777) & 0.0 & 3.4 & 3.7 & 0.4 & 0.7 & 8.7 & 8.9 & 12.3 & 12.1 & 0.6 & 7.7 \\
\hline Myrrha octodecimguttata (Linnaeus, 1758) & 0.0 & 0.0 & 0.0 & 0.0 & 0.0 & 0.4 & 0.2 & 0.0 & 0.0 & 0.0 & 1.6 \\
\hline Myzia oblongoguttata (Linnaeus, 1758) & 0.0 & 0.0 & 0.0 & 0.0 & 0.2 & 0.0 & 0.0 & 0.0 & 0.0 & 0.0 & 0.5 \\
\hline Oenopia conglobata (Linnaeus, 1758) & 0.0 & 0.0 & 0.0 & 0.0 & 0.0 & 0.0 & 0.0 & 0.0 & 0.7 & 0.0 & 0.0 \\
\hline Propylea quatuordecimpunctata (Linnaeus, 1758) & 0.0 & 0.0 & 0.0 & 0.0 & 0.0 & 0.0 & 0.0 & 0.0 & 0.0 & 0.0 & 0.5 \\
\hline Subcoccinella vigintiquatuorpunctata (Linnaeus, 1758) & 1.1 & 0.0 & 0.0 & 0.0 & 0.0 & 2.9 & 2.2 & 0.7 & 0.0 & 0.0 & 1.1 \\
\hline Scymnus suturalis Thunberg, 1795 & 0.0 & 0.0 & 0.0 & 0.0 & 5.9 & 0.0 & 0.0 & 0.0 & 0.0 & 0.0 & 14.8 \\
\hline Number of individuals $(\mathrm{N})$ & 461 & 174 & 109 & 270 & 426 & 756 & 827 & 438 & 141 & 180 & 183 \\
\hline Number of species (S) & 11 & 9 & 7 & 6 & 13 & 12 & 13 & 8 & 7 & 4 & 12 \\
\hline Simpson's index of diversity & 0.73 & 0.61 & 0.66 & 0.26 & 0.72 & 0.71 & 0.75 & 0.76 & 0.69 & 0.17 & 0.83 \\
\hline
\end{tabular}



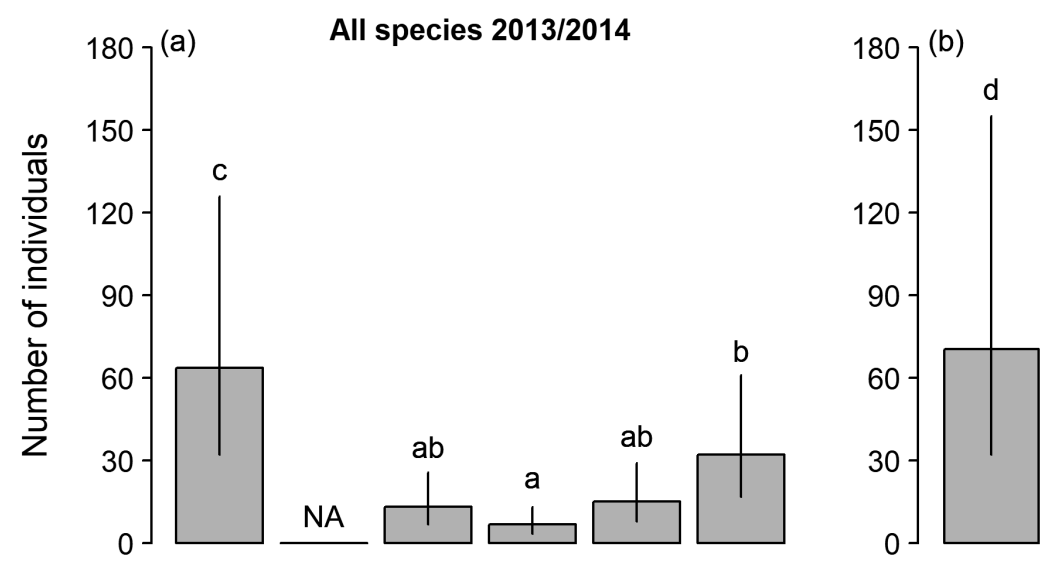

All species 2014/2015
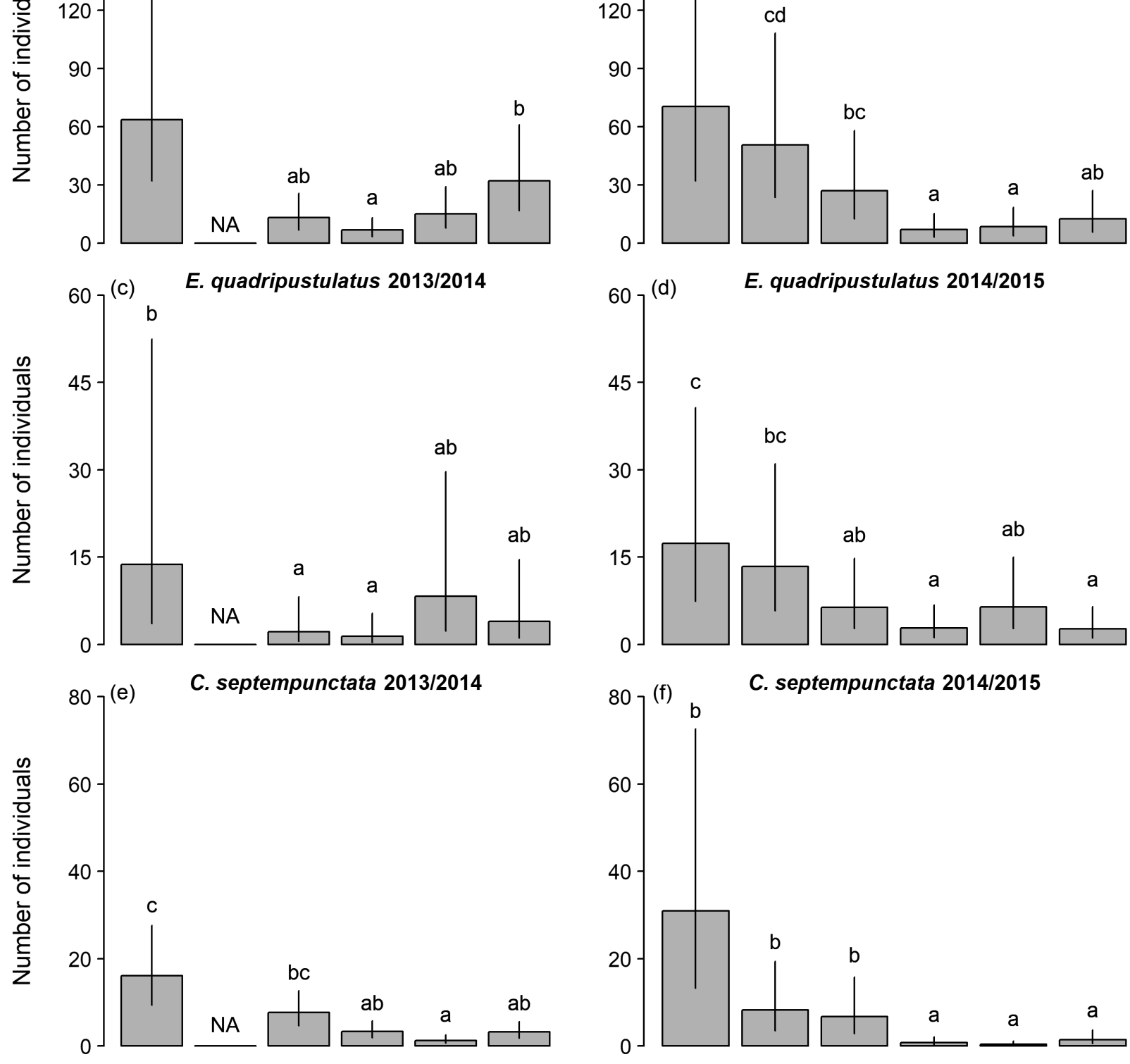

E. quadripustulatus 2014/2015
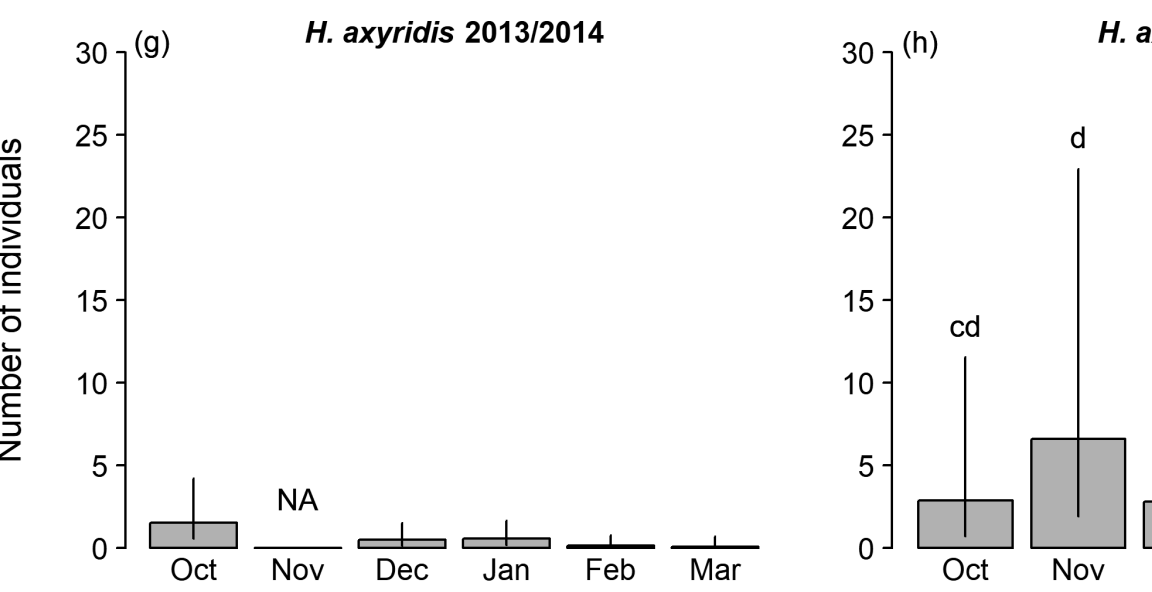

H. axyridis $2014 / 2015$

Fig. 3. Number of ladybirds $(\mathrm{N})$ on 200 branches (1 m long each) of Scots pine trees. All ladybirds (a, b), Exochomus quadripustulatus (c, d), Coccinella septempunctata (e, f) and Harmonia axyridis (g, h). October 2013-March 2014 (a, c, e, g), October 2014 -March 2015 (b, $d, f, h)$. Columns denote the mean. The meaning of error bars and letters above the error bars as in Fig. 2. NA - not available. 
$2013 / 2014$

(a)

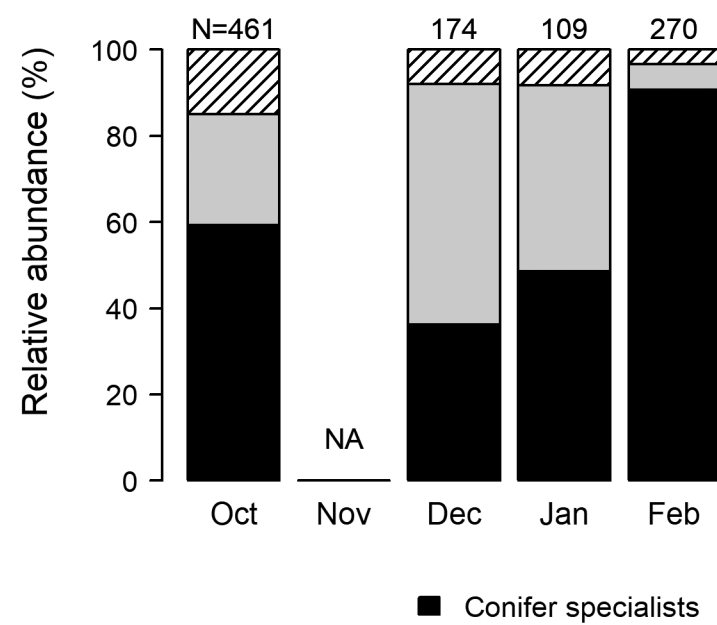

(b)

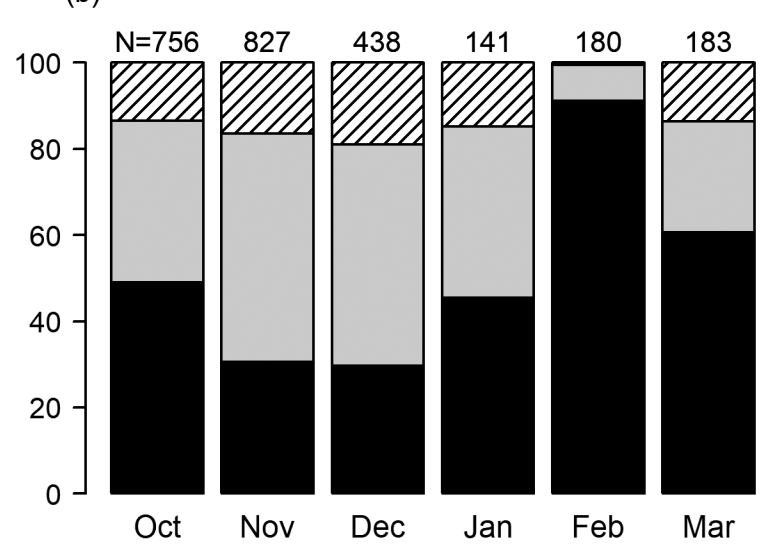

Fig. 4. Ladybird species within host plant categories and their relative abundance (\%). Conifer specialists: Myrrha octodecimguttata, Coccinella magnifica, Scymnus suturalis, Rhyzobius chrysomeloides, Harmonia quadripunctata, Exochomus quadripustulatus, Myzia oblongoguttata, Anatis ocellata; generalists: Coccinella septempunctata, Harmonia axyridis, Propylea quatuordecimpunctata; non-conifer dwelling species: Chilocorus bipustulatus, Chilocorus renipustulatus, Calvia decemguttata, Oenopia conglobata, Coccinella quinquepunctata, Coccinula quatuordecimpustulata, Hippodamia variegata, Hippodamia tredecimpunctata, Subcoccinella vigintiquatuorpunctata. October 2013 -March 2014 (a), October 2014-March 2015 (b). N - total number of ladybirds sampled, NA - not available.

in both winters. Only three $(37.5 \%)$ of the eight conifer specialists (see below), E. quadripustulatus, Rhyzobius chrysomeloides (Herbst) and Harmonia quadripunctata (Pontoppidan), were recorded in both periods in more than one winter month (Tables 1, 2).

The abundance of ladybirds (all species) changed over the first $\left(\chi_{(4)}^{2}=131.6, P<0.0001\right)$ and the second period $\left(\chi_{(5)}^{2}=230.5, P<0.0001\right)$. Compared to late autumn, ladybirds were much less abundant during winter, showing an insignificant increase in number in early spring (Fig. $3 \mathrm{a}, \mathrm{b})$. Considering the dominant species, the abundance of E. quadripustulatus changed over the first $\left(\chi_{(4)}^{2}=36.8, P\right.$ $<0.0001)$ and the second period $\left(\chi_{(5)}^{2}=199.7, P<0.0001\right.$, Fig. 3c, d) with an insignificant increase in February. The abundance of $C$. septempunctata also varied over time $\left(\chi_{(4)}^{2}\right.$ $\left.=130.5, P<0.0001 ; \chi_{(5)}^{2}=3237.2, P<0.0001\right)$, being lowest and continually decreasing during winter (Fig. 3e,f). Harmonia axyridis was scarce in the first period (not tested, Fig. $3 \mathrm{~g}$ ) but increased in number in the second period $\left(\chi_{(5)}^{2}=38.5, P<0.0001\right)$ when its abundance was highest in November and lowest in February (Fig. 3h).

Ladybird assemblages, according to host preferences of species, constituted species in three categories. Nine species ( $45 \%$ of species) were non-conifer dwelling, preferring broadleaved trees - Chilocorus bipustulatus (Linnaeus), Chilocorus renipustulatus (Scriba), Calvia decemguttata (Linnaeus), Oenopia conglobata (Linnaeus) or herbaceous plants - Coccinella quinquepunctata Linnaeus, Coccinula quatuordecimpustulata (Linnaeus), Hippodamia variegata, Hippodamia tredecimpunctata (Linnaeus), Subcoccinella vigintiquatuorpunctata (Linnaeus). Eight species $(40 \%)$ were conifer specialists preferring pines - Myrrha octodecimguttata (Linnaeus), Coccinella magnifica Redtenbacher, Scymnus suturalis Thunberg, Rhyzo- bius chrysomeloides, Harmonia quadripunctata, or having a broader range of conifer species as hosts - Exochomus quadripustulatus, Myzia oblongoguttata (Linnaeus), Anatis ocellata (Linnaeus). Three species (15\%) were generalists found on both non-conifer and conifer trees as well as on herbaceous plants - Coccinella septempunctata, Harmonia axyridis and Propylea quatuordecimpunctata (Linnaeus). The proportions of the three species categories were consistent between the first and the second period (similar pattern), showing an increase in share of conifer specialists during winter due to the prevalence of E. quadripustulatus (Fig. 4a, b). The diversity of species assemblages of ladybirds tended to decrease from late autumn towards winter. It was consistently lowest in February (Table 2).

The composition of overwintering species assemblages of ladybirds showed a significant temporal variation (pseudo-F $=3.5, P<0.001$ ) and also varied with the age of pine stand (pseudo-F $=4.1, P=0.003$ ). The temporal factor (month) explained $25 \%$ and the spatial factor (stand) explained $5.8 \%$ of the variability in species data (total inertia $=1.3726$ ). The number of overwintering ladybirds (December-February) varied greatly between the stands of different ages (range/1st period: 6-171, $\mathrm{n}=10$; range/2nd period: 6-299 individuals, $n=10$ ). It was consistently (over both periods) lowest in the youngest of the stands (five years old). For overwintering, ladybirds mostly utilized the stands that were at least 15 years old. The type of habitat adjacent to an overwintering habitat of ladybirds (forest, no forest) did not influence composition of overwintering species assemblages (pseudo-F $=0.9, P=0.651$ ).

\section{DISCUSSION}

Our results provide the first insights into temporal (phenological) changes in species assemblages of ladybirds on 
Scots pine in Central Europe from late autumn to early spring. They reveal the importance of the lower branches of pines as a habitat for at least 20 ladybird species (of them 13 overwintering, 4 continually), that is, more species than Bastian (1982) recorded on young Scots pines during the growing season (17 species) or Czechowska (1995a) reported from the canopies of Scots pine stands of different ages during the growing season and in early autumn (14 species).

Of the conifer specialists, only E. quadripustulatus was frequently recorded during the whole overwintering period. This species overwinters on evergreen trees and shrubs, particularly in pine foliage (Roy et al., 2011), bark crevices and litter (Bielawski, 1961; Hodek, 2012a; Nedvěd, 2015), or on pine branches, as shown in this study. The reproductive activity of E. quadripustulatus starts very early, an increasing number of individuals on trees can be observed in February (Nedvěd, 2015), in agreement with our results.

Adult $C$. septempunctata often rest at the ends of twigs of young pines before they drop and shelter on the ground (Hodek, 1960; Bielawski, 1961; Klausnitzer, 1967). We (O. Nedvěd, unpubl.) observed this behaviour between 1995 and 2010 in a forest margin in South Bohemia where adult $C$. septempunctata were often present on pines until November and moved to the litter in December. Herein, for the first time, we demonstrated the continual overwintering of adult C. septempunctata on the lower branches of Scots pine until spring, proving that at least some of them avoid dropping to low herbage, litter, small stones or dead standing herbs - the preferred overwintering sites of this species (Honěk, 1989; Honěk et al., 2007). Compared to Central Europe, in Britain the known range of overwintering sites of C. septempunctata is broader, and overwintering individuals are known to utilize buildings, crevices in tree trunks and the foliage of gorse (Ulex spp.) and conifers, in some cases as high as $15 \mathrm{~m}$ above ground level (Majerus, 1994). As C. septempunctata was intensively studied in Central Europe (Hodek, 1973; Honěk \& Martinková, 2005; Hodek, 2012a) it is unlikely that its overwintering on conifers prior to this study was overlooked. The contrast in overwintering site choices of $C$. septempunctata between Britain and Central Europe suggests that the mild British maritime climate favours the overwintering of this species on trees compared to the colder climate of continental Europe (Majerus, 1994). The winters of 2013/2014 and $2014 / 2015$ both were mild for much of the time and among the five mildest in Slovakia since 1950 (data source: Slovak Hydrometeorological Institute, 2016). The mild winter weather may have supported the unexpected persistence of both $C$. septempunctata and $H$. variegata on exposed branches of pine trees. Adult $H$. variegata typically require leaf litter and/or dry grass as an overwintering habitat (Majerus, 1994; Roy et al., 2011; Nedvěd, 2015) but they may be overwintering on Scots pine trees as well.

Of the factors influencing recording of ladybirds on branches of Scots pine trees, fluctuations of abundance in species such as $C$. septempunctata (cf. Honěk \& Martinková, 2005; Selyemová et al., 2007; Honěk et al., 2016;) or
H. axyridis (low abundance in the first period but high in the second) need special consideration in the winter surveying of ladybirds. Some ladybirds may have fallen off the sampled branches and moved to other trees and other branches as a result of beating. The probability that this, or the movement of ladybirds to other habitats, could influence the temporal and/or spatial variation in species assemblages was very low, judged from the negligible number of branches and trees sampled in comparison to the number of trees across all investigated sites.

The overwintering of $H$. axyridis in coniferous forests, and specifically on Scots pine, has not previously been considered using systematically collected data. The known overwintering habitats of $H$. axyridis in nature include crevices in rocks and the bark of standing or fallen trees, including Scots pine, and overwintering adults are also found under the bark or underneath fallen logs (Hodek, 2012a; Pendleton \& Pendleton, 1997-2016). In the Czech Republic, we (O. Nedvěd, unpubl.) have rarely recorded adult $H$. axyridis overwintering in an empty wasp nest and in a bee hive (a single record in both cases). Six years after its arrival and establishment in Slovakia (Brown et al., 2011; Panigaj et al., 2014), over the period 2014-2015, $H$. axyridis became the third most abundant ladybird species on Scots pine. Adults remained active on pine trees until mid-November, following the main dispersal time in October (Panigaj et al., 2014). The decreasing abundance of $H$. axyridis on pines later in the winter parallels the trends in Britain (Roy et al., 2011; Roy \& Brown, 2015) where adults are extremely difficult to find openly on Scots pine and their outdoor winter records are rare (Pendleton \& Pendleton, 1997-2016).

Other ladybird species were collected less frequently from branches. Adult M. octodecimguttata overwinter on the lowest portion of tree trunk (the tree butt) of Scots pine (Pulliainen, 1966) or in the litter (Nedvěd, 2015), and adult $C$. magnifica spend the winter near Formica ant nests, in leaf litter, dead bracken fronds, heather and pine foliage (Majerus, 1994). Adult S. suturalis overwinter under the bark of Scots pine near the tree base (Majerus, 1994; Nedvěd, 2015) or in moss (Roy et al., 2011), and we recorded them on branches in mid-March after leaving hibernacula. In the pine forest $S$. suturalis possibly entered overwintering sites before mid-October, unlike in Britain where this species may be found on pines until at least mid-October (P.M.J. Brown, pers. observ.). Adult $A$. ocellata spend the winter in soil (Roy et al., 2011) or leaf litter (Kučera, 1955; Nedvěd, 2015), and adult M. oblongoguttata choose moss pads or leaf litter as overwintering habitats (Roy et al., 2011; Nedvěd, 2015). Accordingly, we did not record these conifer specialists spending winter on pine branches. Another conifer specialist, H. quadripunctata, was only rarely found during winter. This species overwinters in the bark crevices or under the bark of Scots pine, rarely amongst pine foliage (Majerus, 1994; Roy et al., 2011; Nedvěd, 2015).

Our study revealed that species assemblages of ladybirds changed in the mild winter weather and were affected by 
the age of pine stand. The significant effect of this site factor could reflect species' preferences for selecting particular stands earlier during the growing season (cf. Bastian, 1982, 1984; Czechowska, 1995a) or during autumn dispersal (Galecka, 1991). The preference for stands of Scots pine at least 15 years old could be explained by better protection of adults against abiotic factors (wind, rain or snow) in these stands.

All of the ladybirds collected during winter were alive. This demonstrates successful survival of native species and $H$. axyridis on pine branches, although mortality was not assessed. According to McClure (1987) only $10 \%$ of caged adult $H$. axyridis survived a cool winter in North America with a mean temperature in January of $-5.8^{\circ} \mathrm{C}$ and a minimum temperature in January of $-17.8^{\circ} \mathrm{C}$. The lethal temperatures for adult $H$. axyridis in outdoor hibernacula vary from -17.1 to $-16.3^{\circ} \mathrm{C}$ (Berkvens et al., 2010). In our study the lowest air temperatures in the winter of $2013 / 2014\left(-11.5^{\circ} \mathrm{C}\right.$ in January) and $2014 / 2015\left(-13.3^{\circ} \mathrm{C}\right.$ in December) were above the lethal values, hence, the mild winter weather probably reduced the mortality risk of this species, which is considered eurythermic (Barahona-Segovia et al., 2016). Resistance of ladybirds to subzero temperatures is high in the middle period of dormancy, however, early or late frosts can be very damaging (Hodek, 1973). An exception is E. quadripustulatus which can quickly acclimitise to low temperatures after activation from dormancy (Nedvěd, 1995).

Uncertainties about the effects of climate change on ecosystems highlight the need for thorough studies of species and communities (Campbell et al., 2005; Bale \& Hayward, 2010; Bellard et al., 2012). The predictions of climate change within Europe for 2080 and 2100 show a robust and significant increase in both January and annual mean temperatures (Murphy, 2000; Jacob et al., 2014). In the continental climate of Central Europe ladybirds are expected to experience increasing fluctuation in winter weather both within and between years. As the winters of 2013/2014 and $2014 / 2015$ were both exceptionally mild, the recorded species assemblages could differ from those in harsh winters. Therefore long term data, spanning various winter weather conditions, are needed to better predict ladybird responses to changing weather or different climates.

Our results suggest that Scots pine, being widely distributed (Rehfeldt et al., 2002), could be suited to winter surveying of ladybirds at large spatial scales. However, more research is required to assess the effect of spatial factors such as the forest type (monospecific pine stands vs. heterospecific stands with pine), forest margin aspect, sampling heights from trees (lower vs. upper branches) to optimize the surveys with regard to sampling effort, comparability of data and reliability of results. As the probability of recording ladybird species on the branches of Scots pine trees can be low during winter, judged from low values of relative occurrence for most recorded species in our study, high numbers of samples are required to enable robust quantitative data analyses.
The results verified our predictions. (1) Ladybird assemblages on Scots pine during winter constituted fewer species than were recorded in late autumn or early spring. (2) Overall abundance of ladybirds decreased from autumn to winter and remained lowest during this most hazardous time of the year for ladybirds, this temporal pattern being common to most species. (3) Species assemblages of overwintering ladybirds in pine forest showed a significant temporal and spatial variation.

Further studies are required on the ultimate causes of temporal changes in species assemblages of ladybirds on Scots pine, such as photoperiod and temperature (Hodek, 2012a, b), and their trends and synergistic effects, as determinants of behavioural responses of ladybird species.

ACKNOWLEDGEMENTS. The study was supported by the grants VEGA 1/0066/13, VEGA 2/0052/15, VEGA 2/0012/17 (Scientific Grant Agency of Ministry of Education), APVV 14/0567, GA JU 152/2016/P (University of South Bohemia), GACR 1706763S (Czech Science Foundation), Institutional Support of MZe ČR, and COST Action TD 1209.

\section{REFERENCES}

Adriaens T., San Martin y Gomez G. \& Maes D. 2008: Invasion history, habitat preferences and phenology of the invasive ladybird Harmonia axyridis in Belgium. - BioControl 53: 69-88.

BALE J.S. \& HAYward S.A.L. 2010: Insect overwintering in a changing climate. - J. Exp. Biol. 213: 980-994.

Bastian O. 1982: Die Coccinellidenfauna einiger Koniferenjungwüchse des Tharandter Waldes. - Faun. Abh. Staatl. Mus. Tierk. Dresden 20: 211-223.

BASTIAN O. 1984: Zur Vorkommen und zur Effektivität aphidophager Prädatoren in Koniferenjungwüchsen des Tharandter Waldes. - Zool. Jb. Syst. 111: 245-279.

Barahona-Segovia R.M., Grez A.A. \& Bozinovic F. 2016: Testing the hypothesis of greater eurythermality in invasive than in native ladybird species: from physiological performance to life history strategies. - Ecol. Entomol. 41: 182-191.

Bellard C., Bertelsmeier C., Leadley P., Thuiller W. \& CourCHAMP F. 2012: Impacts of climate change on the future of biodiversity. - Ecol. Lett. 15: 365-377.

Berkyens N., Bale J.S., Berkvens D., Tirry L. \& De Clerce P. 2010: Cold tolerance of the harlequin ladybird Harmonia axyridis in Europe. - J. Insect Physiol. 56: 438-444.

BIELAWSKI R. 1961: [Coccinellidae (Coleoptera) in herbaceous vegetation and a pine nursery at Warszawa-Bielany.] — Frag. Faun. 8: 485-525 [in Polish].

Bolker B.M., Brooks M.E., Clark C.J., Geange S.W., Poulsen J.R., Stevens M.H.H. \& White J.S.S. 2009: Generalized linear mixed models: a practical guide for ecology and evolution. Trends Ecol. Evol. 24: 127-135.

Brown P.M.J. \& Roy H.E. 2018: Decline in native ladybird species caused by the invasive harlequin ladybird Harmonia axyridis: evidence from a long term field study. - Insect Conserv. Diver. 11: 230-239.

Brown P.M.J., Adriaens T., Batho H., Cuppen J., Goldarazena A., HägG T., Kenis M., Klausnitzer E.M., Kovár̆ I., Loomans A.J.M., Majerus M.E.N., Nedvěd O., Pedersen J., Rabitsch W., Roy H.E., Ternois V., Zakharov I.A. \& Roy D.B. 2008: Harmonia axyridis in Europe: spread and distribution of a nonnative coccinellid. - BioControl 53: 5-21.

Brown P.M.J., Thomas C.E., Lombaert E., Jefrries D.L., Estoup A. \& Handley L.J.L. 2011: The global spread of Harmonia 
axyridis (Coleoptera: Coccinellidae): distribution, dispersal and routes of invasion. - BioControl 56: 623-641.

Campbell J.L., Mitchel M., Groffman P.M., Christanson L.M. \& HARDY J.P. 2005: Winter in northeastern North America: a critical period for ecological processes. - Front. Ecol. Envir. 3: $314-322$.

CERYNGIER P. 2000: Overwintering of Coccinella septempunctata (Coleoptera: Coccinellidae) at different altitudes in the Karkonosze Mts, SW Poland. - Eur. J. Entomol. 97: 323-328.

CzechowsKa W. 1995a: Coccinellidae (Coleoptera) of the canopy layer in pine forests. - Fragm. Faun. 38: 379-388.

CzechowsKa W. 1995b: Neuropteroidea and Coccinellidae (Coleoptera) of pine canopies of the pine forests in the Berezinski Biosphere Reserve in Byelorussia. - Fragm. Faun. 38: 160-163.

Galecka B. 1991: Distribution and role of coccinellids in an agricultural landscape. In Polgár L., Chambers R.J., Dixon A.F.G. \& Hodek I. (eds): Behaviour and Impact of Aphidophaga. SPB Academic Publishing, The Hague, pp. 137-141.

Hammer Ø., Harper D.A.T. \& Ryan P.D. 2001: PAST: Paleontological statistics software package for education and data analysis. - Palaeontol. Electron. 4(1): 4, 9 pp.

HemptinNe J.L. 1985: Dormancy sites of the ladybird Adalia bipunctata (L.) (Col., Coccinellidae) in Belgium. - Acta Oecol. /Oecol. Appl. 6: 3-13.

HemptinNe J.L. 1988: Ecological requirements for hibernating Propylea quatuordecimpunctata (L.) and Coccinella septempunctata (Col.: Coccinellidae). - Entomophaga 33: 505-515.

Hodek I. 1960: Hibernation-bionomics in Coccinellidae. - Čas. Čes. Spol. Entomol. 57: 1-20.

Hodek I. 1973: Dormancy. In Hodek I. (ed.): Biology of Coccinellidae. W. Junk, The Hague, pp. 152-195.

Hodek I. 2012a: Diapause/Dormancy. In Hodek I., van Emden H.F. \& Honěk A. (eds): Ecology and Behaviour of the Ladybird Beetles (Coccinellidae). Blackwell, Chichester, pp. 275-342.

Hodek I. 2012b: Adult Diapause in Coleoptera. — Psyche 2012: 249081, $10 \mathrm{pp}$.

HodeK I. \& HonĚK A. 1996: Ecology of Coccinellidae. Kluwer Academic Publishers, Dordrecht, 463 pp.

HodeK I., vAN EMDEN H.F. \& HoNĚK A. 2012: Ecology and Behaviour of Ladybird Beetles (Coccinellidae). Willey-Blackwell, Oxford, Chichester, $565 \mathrm{pp}$.

HoNĚK A. 1989: Overwintering and annual changes of abundance of Coccinella septempunctata in Czechoslovakia (Coleoptera, Coccinellidae). - Acta Entomol. Bohem. 86: 179-192.

HonĚK A. \& MARTINKOVÁ Z. 2005: Long term changes in abundance of Coccinella septempunctata (Coleoptera: Coccinellidae) in the Czech Republic. - Eur. J. Entomol. 102: 443-448.

HonĚK A., Martinková Z. \& PeKÁR S. 2007: Aggregation characteristics of three species of Coccinellidae (Coleoptera) at hibernation sites. - Eur. J. Entomol. 104: 51-56.

HoněK A., Martinková Z., Dixon A.F.G., Roy H.E. \& PekÁr S. 2016: Long-term changes in communities of native coccinellids: population fluctuations and the effect of competition from an invasive non-native species. - Insect Conserv. Diver. 9: 202-209.

HöREGOTT H. 1960: Untersuchungen über die qualitative and quantitative Zusammensetzung der Arthropodenfauna in den Kieferkronen. - Beitr. Entomol. 10: 891-916.

Jacob D., Petersen J., Eggert B., Alias A., Christensen O.B., Bouwer L.M., Braun A., Colette A., Déqué M., Georgievski G. \& Georgopoulou E. 2014: EURO-CORDEX: new highresolution climate change projections for European impact research. - Reg. Environ. Change 14: 563-578.
KLAusNitZer B. 1965: Beitrag zur Coccinellidenfauna einer Kiefernschonung (Col.). - Mitt. Dt. Entomol. Ges. 24: 45-48.

Klausnitzer B. 1967: Zur Kenntniss der Beziehungen der Coccinellidae zur Kieferwäldern (Pinus silvestris). — Acta Entomol. Bohemoslov. 64: 62-68.

Косн R.L. 2003: The multicolored Asian lady beetle, Harmonia axyridis: A review of its biology, uses in biological control and non-target impacts. - J. Insect Sci. 3: 32, 16 pp.

Kollár J., Balkovič J., Mazúrová A. \& Šimonovič V. 2011: Phytocoenological and production evaluation of the natural oak and secondary pine forests of the Borská nížina lowland. Ekológia (Bratislava) 30: 369-380.

KuČERA V. 1955: [Dreyfusia piceae Ratz. and its enemy Anatis ocellata L.]. - Pr. Výzk. Úst. Lesn. (Zbraslav-Strnady) 8: 107-114 [in Czech].

McClure M.S. 1987: Potential of the Asian predator Harmonia axyridis Pallas (Coleoptera: Coccinellidae) to control Matsucoccus resinosae Bean and Godwin (Homoptera: Margarodidae) in the United States. - Environ. Entomol. 16: 224-230.

MaJERus M.E.N. 1994: Ladybirds. New Naturalist Series no. 81, Harper Collins, London, 367 pp.

MaJerus M.E.N. 2016: A Natural History of Ladybird Beetles. Cambridge University Press, Cambridge, 397 pp.

MuRPHY J. 2000: Predictions of climate change over Europe using statistical and dynamical downscaling techniques. - Int. J. Climatol. 20: 489-501.

NEDVĚD O. 1993: Comparison of cold hardiness in two ladybird beetles (Coleoptera: Coccinellidae) with contrasting hibernation behaviour. - Eur. J. Entomol. 90: 465-470.

NEDVĚD O. 1995: Cold reacclimation in postdormant Exochomus quadripustulatus (Coleoptera: Coccinellidae). - CryoLetters 16: $47-50$.

NEDVĚD O. 2006: Ephemeral overwintering aggregations of ladybirds in South Bohemia. - Silva Gabreta 12: 151-155.

NedvĚD O. 2015: Ladybird Beetles (Coccinellidae) of Central Europe. Zoological Keys. Academia, Praha, 304 pp.

Panigaj L., Zach P., HoněK A., Nedvěd O., Kulfan J., Martinková Z., Selyemová D., Viglášová S. \& Roy H.E. 2014: The invasion history, distribution and colour pattern forms of the harlequin ladybird beetle Harmonia axyridis (Coleoptera, Coccinellidae) in Slovakia, Central Europe. - Zookeys 412: 89-102.

Pendleton T. \& Pendleton D. 1997-2016: Known ladybird overwintering sites. In: The Web Site Dedicated to Nottinghamshire's Invertebrate Fauna. URL: http://www.eakringbirds. com (last accessed 26 Nov. 2018).

Pulliainen E. 1966: On the hibernation sites of Myrrha octodecimguttata L. (Col., Coccinellidae) on the butts of the pine (Pinus silvestris L.). - Ann. Entomol. Fenn. 32: 99-104.

RaAk-van den Berg C.L., Hemerik L., de Jong P.W. \& van LenTEREN J.C. 2012: Mode of overwintering of invasive Harmonia axyridis in the Netherlands. - BioControl 57: 71-84.

R Development Core Team 2016: $R$ : A Language and Environment for Statistical Computing. R Foundation for Statistical Computing, Vienna, URL: http://www.R-project.org.

Rehfeldt G.E., Tchebakova N.M., Parfenova Y.I., Wykoff W.R., KuZmina N.A. \& MiLYUTin L.I. 2002: Intraspecific responses to climate in Pinus sylvestris. - Glob. Change Biol. 8: 912-929.

Roy H.E., Brown P.M.J., Frost R. \& Poland R.L. 2011: The Ladybirds (Coccinellidae) of Britain and Ireland. An Atlas of the Ladybirds of Britain, Ireland, the Isle of Man and the Channel Islands. FSC Publications, Shrewsbury, 198 pp.

Roy H.E., Adriaens T., Isaac N.J.B, Kenis M., Onkelinx T., San Martin y Gomez G., Brown P.M.J., Hautier L., Poland R., RoY D.B. ET AL. 2012: Invasive alien predator causes rapid 
declines of native European ladybirds. - Divers. Distrib. 18: $717-725$.

Roy H.E. \& BRown P.M.J. 2015: Ten years of invasion: Harmonia axyridis (Pallas) (Coleoptera: Coccinellidae) in Britain. Ecol. Entomol. 40: 336-348.

Roy H.E., Brown P.M.J., Adriaens T., Berkvens N., Borges I., Clusella-Trullas S., Comont R.F., Clerce P., De Eschen R., Estoup A. ET AL. 2016: The harlequin ladybird, Harmonia axyridis: global perspectives on invasion history and ecology. Biol. Invas. 18: 997-1044.

Selyemová D., Zach P., Némethová D., Kulfan J., Úradník M., Holecová M., KrŠiaK B., Vargová K. \& OlšovskÝ T. 2007: Assemblage structure and altitudinal distribution of lady beetles (Coleoptera, Coccinellidae) in the mountain spruce forests of Pol'ana Mountains, the West Carpathians. - Biologia (Bratislava) 62: 610-616.
SlogGett J.J. 2017: Harmonia axyridis (Coleoptera: Coccinellidae): Smelling the rat in native ladybird declines. - Eur. J. Entomol. 114: 455-461.

ŠoMŠÁK L. \& KuBíčEK F. 1994: Phytocoenological and production evaluation of the original and secondary pine forests of the Záhorská nížina lowlands. I. Alliance Pino-Quercion. Ekológia (Bratislava) 13: 335-348.

ŠT̃astný P., Bochníček O., FašKo P., NeJedlík P. \& Snopková Z. 2015: Climate Atlas of Slovakia. Slovak Hydrometeorological Institute, Bratislava, $132 \mathrm{pp}$.

Viglášová S., Nedvěd O., Zach P., Kulfan J., Parák M., HoněK A., Martinková Z. \& Roy H. 2017: Species assemblages of ladybirds including the harlequin ladybird Harmonia axyridis: a comparison at large spatial scale in urban habitats. - BioControl 62: 409-421.

Received February 21, 2018; revised and accepted November 8, 2018 Published online December 4, 2018 